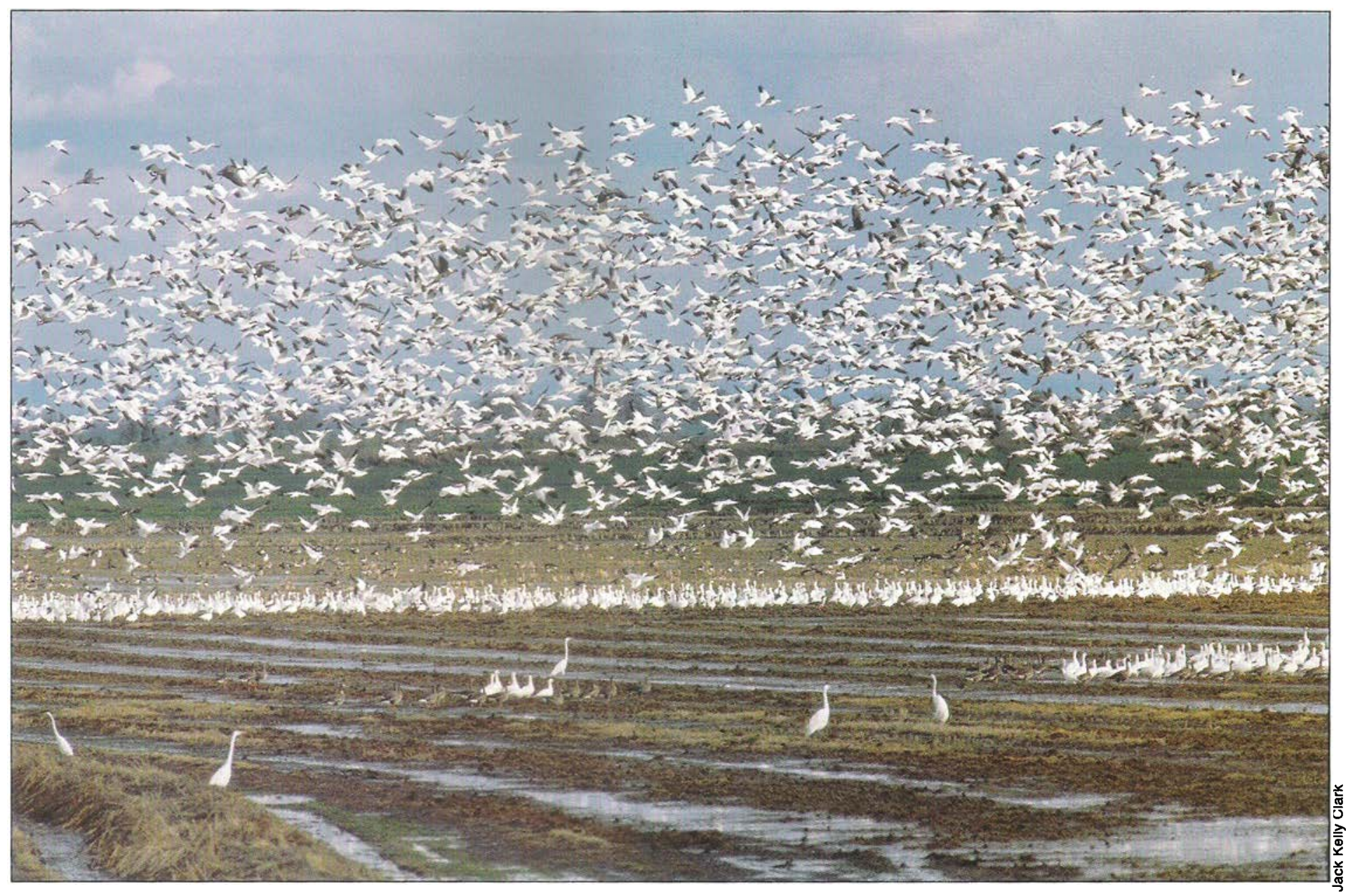

In the 21st century, California must determine how to distribute water equitably among agriculture, people and nature. Farmers are learning to coexist peacefully with birds such as snow geese, which glean from fields during the winter.

\title{
Is California's future hydraulically sustainable?
}

Richard E. Howitt

The term "hydraulic society" describes the ancient cities and social systems that relied on irrigated agriculture, such as Egypt's Nile Valley. For 5,000 years, the annual cycle of floods replenished the Nile region's soil and nutrients, eliminating the need for complex canal systems such as those found in the Sumerian and Mesopotamian regions. California is the first hydraulic society that is rapidly developing into a postindustrial economy; this change will require the partial reallocation of our water resources. California should attempt to move toward a decentralized, resilient "ancient Egyptian" model of water allocation rather than continue with a centralized but less responsive "Mesopotamian" model. A hydraulic society can be destabilized by drought conditions, degradation of water quality, and the inability of distribution systems to adapt to social or economic changes. Although hydraulic societies are ecologically unstable due to their modification and specialization of the ecosystem, changing the system of social feedback can compensate for this rigidity.
Tistorian Karl Wittfogel coined the Iterm "hydraulic society" to describe the ancient cities and social systems that relied on the productivity of irrigated agriculture (Wittfogel 1957). These societies generated the surplus production needed to stimulate and sustain the development of writing, laws, public works and government control. Wittfogel's central idea was that irrigated agriculture provided both the wherewithal and the need for central leadership, and thus led to the evolution of political and social structures that could construct and manage large-scale irrigation systems.

Many writers before and after Wittfogel have focused on the collapse 

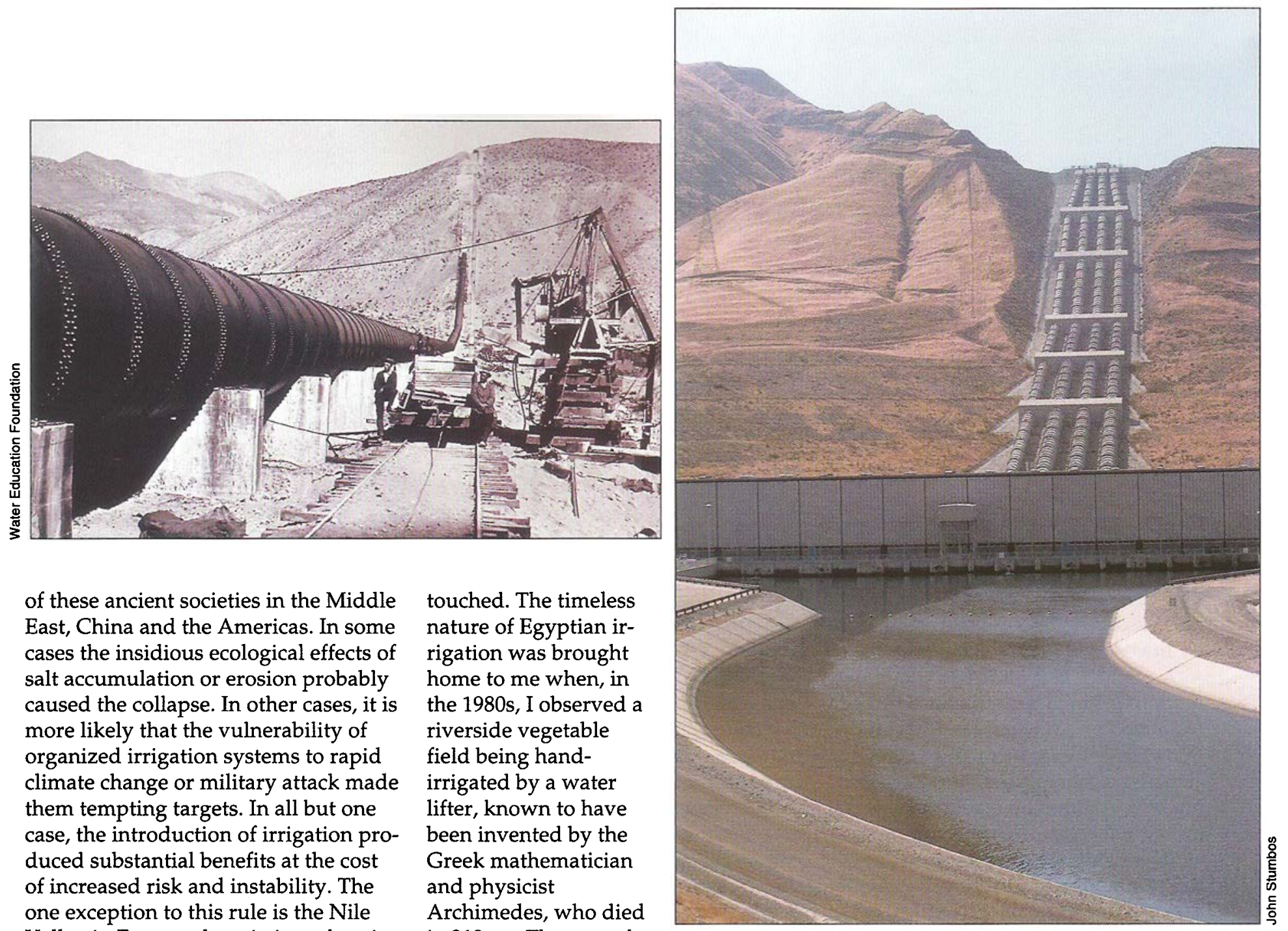

of these ancient societies in the Middle East, China and the Americas. In some cases the insidious ecological effects of salt accumulation or erosion probably caused the collapse. In other cases, it is more likely that the vulnerability of organized irrigation systems to rapid climate change or military attack made them tempting targets. In all but one case, the introduction of irrigation produced substantial benefits at the cost of increased risk and instability. The one exception to this rule is the Nile Valley in Egypt, where irrigated agriculture has been practiced for 5,000 years. The reason for the success and sustainability of Egyptian irrigated agriculture is that until recently the annual cycle of Nile floods replenished the soil and nutrients. And perhaps more importantly, it restricted the intensity of cropping in the valley.

In addition to their natural fertility, the floods had the advantage that they greatly reduced the need for complex canal systems such as those found in Sumerian and Mesopotamian regions. The ability of Egyptian farmers to direct the annual flood onto their fields without complex canal systems yielded a more resilient social structure for irrigated production. Egypt has suffered from waves of foreign invaders and rulers over the past 2,000 years, but the productivity and practice of irrigation continued largely un- touched. The timeless nature of Egyptian irrigation was brought home to me when, in the 1980s, I observed a riverside vegetable field being handirrigated by a water lifter, known to have been invented by the Greek mathematician and physicist Archimedes, who died in 212 в.C. The central despotic power structure that Wittfogel thought was necessary for all hydraulic societies arose from the irrigation production surplus in Egypt, but was not needed to sustain the agricultural system.

\section{Postindustrial/agricultural economy}

The point of this digression into history is that California is the first hydraulic society that is rapidly developing into a postindustrial economy; this change will require the partial reallocation of California's water resources. California should attempt to move toward a decentralized, resilient "ancient Egyptian" model of water allocation rather than continue with a centralized but less responsive, "Mesopotamian" model. Archaeological evidence points to the central hierarchy led by the priests, implying that
During the last century, California transformed Itself into a hydraulic society, moving water great distances for irrigation and urban development. Above left, In 1913 the Los Angeles/Owens River Aqueduct was completed to siphon water for Southern California's burgeoning population. Above, The California Aqueduct transports water in the San Joaquin Valley.

The timeless nature of Egyptian irrigation was brought bome to me when, in the 1980s, I observed a riverside vegetable field being hand-irrigated by a water lifter, known to have been invented by Archimedes. 


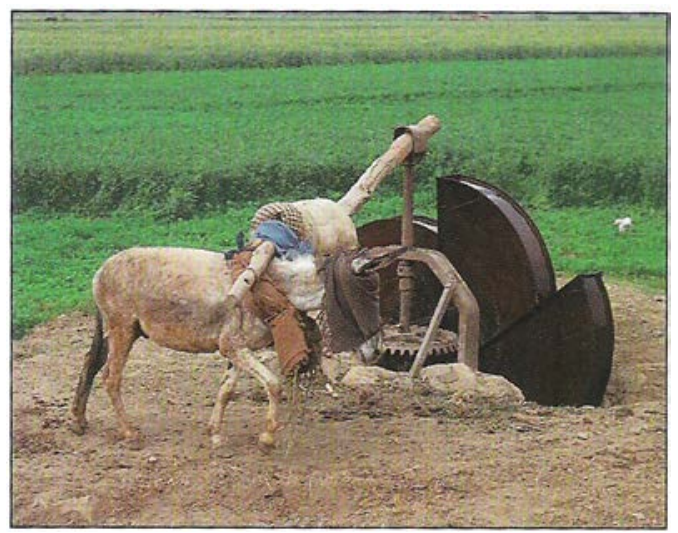

A donkey-driven water pump highlights the timeless nature of Egyptian agriculture.

order and thus information only flowed in one direction. The problem is how to graft a decentralized, userdriven allocation system for water onto a physical infrastructure that has most of the storage and transfer capacity in very large centralized units.

A possible answer lies in combining modern information systems with oldfashioned price incentives. Information can now be transmitted very cheaply to thousands of water users, but that information is relevant only if individuals perceive some gain from acting on it. It should be emphasized that there are significant physical differences between the Californian and Egyptian irrigation systems. However, the constraints and capabilities that occurred naturally in the ancient Egyptian system can be replicated in California by changing the system that developed our hydraulic society, that is by changing government funding and centralized political decision-making.

My use of the term postindustrial/ agricultural economy underscores that I see a vibrant agricultural economy as part of California's future development. The shift in California's economy from a base in irrigated agriculture and industry to a service-based and creative, postindustrial economy is unlikely to reduce economic production from irrigated agriculture for two reasons.

First, California has a comparative advantage in "specialty" crops, which have markets that expand as income

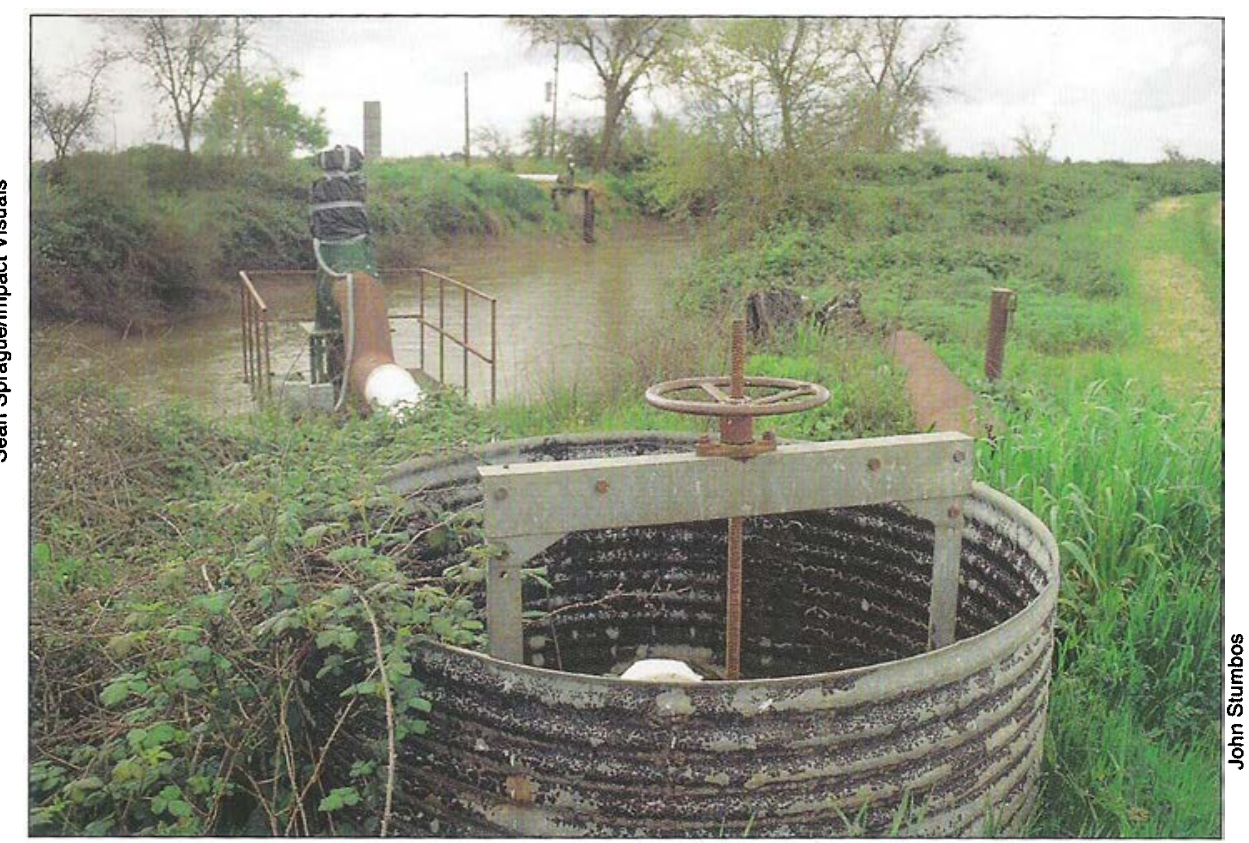

modification of the ecosystem, but flexible adaptations, such as market-driven water distribution, can compensate for rigidity.

grows. The market for Californian fruits, nuts and vegetables can be expected to continue expanding and to require an increasing proportion of the irrigated area. The value of water on these crops is such that, at current prices and efficiencies, this high-valued agriculture generates returns similar to some urban landscape uses and the cost of urban water conservation.

Second, agriculture's amenity value to the urban dweller is growing. As urban expansion continues in the Central Valley, the strips of agricultural land on either side of the linear city that Highway 99 seems destined to become, will have substantial amenity value to the inhabitants who cannot escape the linear city by driving north or south. Wealthy but densely populated industrial societies become highly protective of their remaining agriculture, provided it generates amenity benefits for them, such as selffinancing open space and groundwater recharge. Japan and Switzerland are prime examples of urban-supported amenity agriculture. The Swiss have even gone so far as occasionally using helicopters to fly cows to their winter quarters from mountain pastures. This transportation method costs more than the capital value of the cow, but en- sures that spectacular Swiss alpine pastures remain at the correct grazing pressure.

\section{Water delivery and social stability}

History tells us that hydraulic societies can be destabilized by a combination of three factors: water-quantity failure under drought conditions, gradual degradation of the water quality by salt (or chemical-contaminant) accumulation in the topsoil or aquifers (see p. 43), and the inability of the water-allocation system to adjust to social or economic changes.

A social system with many competing agents is more stable than one in which decisions are centralized. There is a close analogy between a correctly functioning market system and a biodiverse ecosystem. In a biodiverse ecosystem, many species are in competition for limited resources. The range of physical and genetic diversity among the species does not always result in a balanced population, but the existence of diverse potential competitors means that if the system is perturbed, there are several alternative species that can adapt to the new resource situation (see p. 26). In social systems, stability does not come from the ability to predict changes, but from 
the ability to adapt to unpredictable changes. A market in which there are many competing agents with different abilities to use the resource to deliver economic and environmental services will be able to adjust to unpredicted changes.

Although no simple solutions are available, the current changes toward market structures in the California water system can simultaneously address all three causes of instability.

Water supply in dry years. The future California economy will require an environmentally benign system of water supply for dry and drought years. The current move to view water as a commodity, with an uncertain supply that can be priced and allocated by a market structure, can simultaneously address the need for a flexible drought response and water reallocation in the face of a changing economy and public priorities.

A stable hydraulic society based on an inherently fluctuating water supply must have either sufficient storage capacity to outlast long droughts or a water demand system that can flexibly adjust to the changing supplies. Given the current economic, political and environmental costs of substantially expanding surface-storage dams in California, alternatives seem inevitable, such as flexible cropping or the "conjunctive use" of agricultural groundwater. In the latter use, groundwater aquifers act as underground reservoirs that are recharged with surface water in wet years (see p. 56).

A flexible irrigated cropping system from which farmers will voluntarily sell water for dry-year urban uses can play this role. The drought water banks of 1991, 1992 and 1994, despite some problems, provided water at costs substantially lower than building new storage dams. This amenity product from agriculture need not disrupt rural communities that depend on agriculture and related services for employment. Agriculture currently uses $75 \%$ to $80 \%$ of the state's developed water supply, and urban, residential

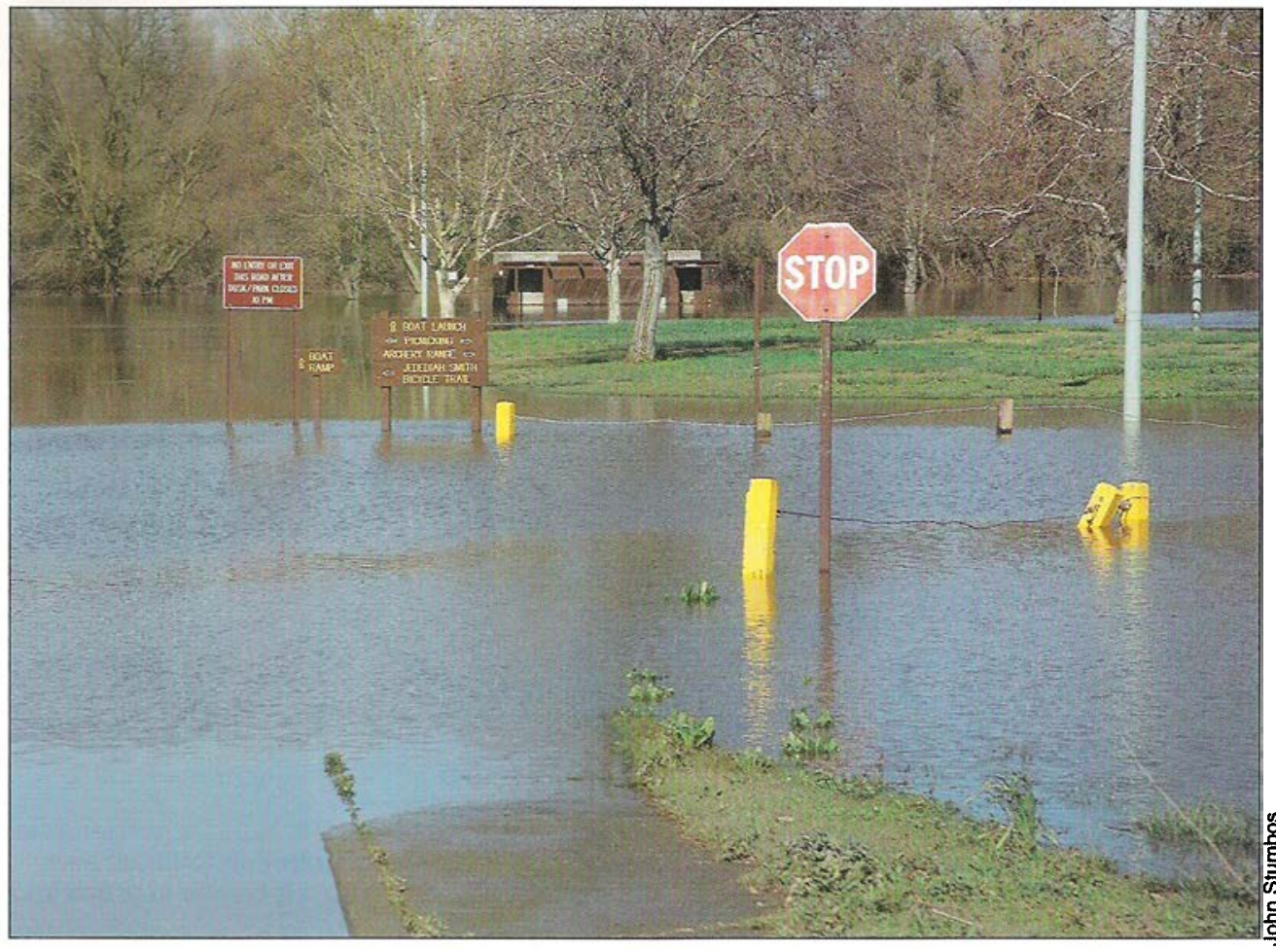

During winter storms, Discovery Park at the confluence of the American and Sacramento rivers frequently floods. Creative and environmentally benign methods are needed to store water in wet years for times of drought.

and industrial uses account for $20 \%$. A $10 \%$ reduction in agricultural use could yield a $40 \%$ increase in urban supplies in a dry year. Likewise, the crops that generate the majority of rural jobs are perennial fruit, nut and vegetable crops, which can compete with urban water values. Reductions in crop acreage would come from field crops, which would have a lower impact on employment and secondary purchases. Field crops, which are more flexible to grow and market, have substantially lower impacts on the regional economies per unit of water.

Another way of viewing this change in water supply is to substitute information for water. The information needed to implement a voluntary and mutually beneficial dry-year transfer from agriculture to urban and amenity uses such as fish flows come from two different sources. Environmental and third-party impacts of potential transfers are best addressed by centralized technical information. In contrast, efficient transfers rely on the detailed local knowledge of water use and value, known only to the ultimate user of the water. Therefore, we need to connect these knowledge sources by cheap and effective channels, and to couple it with an impartial pricing system, so water can flow between the sectors in response to changing economic and hydraulic conditions. Market prices are highly effective channels for conveying information about the current water situation. The price offered for water condenses a wide range of values and preferences into a single signal that is readily understood and usually persuasive.

The price of water. Water prices are also efficient in preventing or compensating the third-party effects of water transfers. A simple example of environmental cost is the additional charge for carriage water needed to balance flows in the Sacramento Delta. Carriage water is the additional water needed to balance the saltwater intrusion when a unit of water is conveyed across the Delta and exported. Balance should be achieved to maintain San Francisco Bay-Delta water quality for everyone. During the 1991 drought, a $30 \%$ carriage water requirement was agreed on, and the drought water bank quoted a sale price for delivery 


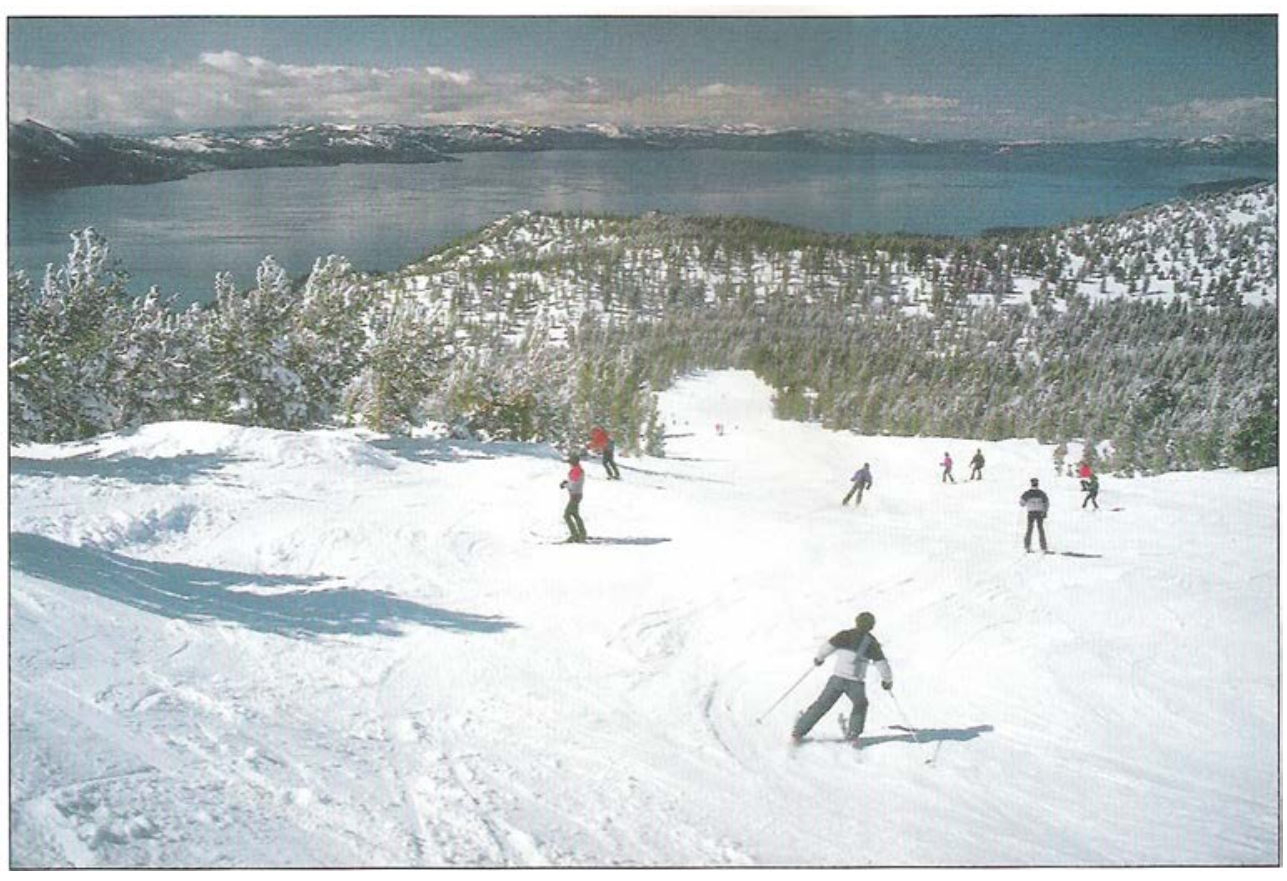

Much of the snowpack melting in the Sierra is destined for redistribution to farms and cities below. A $10 \%$ reduction in agricultural use could yield a $40 \%$ increase in urban supplies during dry years.

below the Delta of $\$ 175$ per acre-foot, which was $30 \%$ above the $\$ 125$ purchase price. In the future, a more sophisticated system of environmental control and mitigation will evolve. Environmental managers should be given the same flexibility of alternative methods to meet their goals as other water users.

A water transfer program and an environmental water account are proposed as part of the CALFED solution to the contentious reallocation of San Francisco Bay-Delta water supplies (CALFED 1999) (see p. 16). Under this program, an environmental manager of the Delta would be allowed to trade levels of standards at different times of the year for additional water in critical periods or for environmental mitigation. Instead of fixed standards, the environmental manager would trade standards to make more efficient use of the flows.

The current uncertain and fluctuating demands for environmental water are similar to the situation that air pollution regulators faced 10 years ago. By adopting a flexible system that enabled industrial plants and public power and transportation utilities to trade their pollution loads, acid-rain air pollution was reduced more than predicted and at a substantially lower cost than the central command systems originally proposed (Kerr 1998). Similar increases in environmental efficiency should be achievable in the water sector. Among the uncertainties was the unexpected situation with the delta smelt in 1999, illustrating the need for flexible alternatives in the management of complex environmental systems. A delay in the movement of delta smelt away from the area near export pumps caused a severe reduction in the ability to move water through the Delta during the peak irrigation season, resulting in agricultural and urban delivery cuts. The conflict over the implementation of the pumping ban could have been avoided if the environmental manager had additional assets such as the ability to draw on stored water south of the Delta. To do this, the manager would have needed either water or money.

In normal water years, California's groundwater resources supply $40 \%$ of the developed supply. In dry and drought years, the proportion of groundwater increases to $60 \%$ of the supply. The groundwater supply has two sources of value, one as normal supplies and the other as a droughtyear buffer that collects much of its re- charge from surface water applied to irrigated crops in normal years. California's groundwater is the least fettered in the western United States. The absence of any measurement or quantified property rights over California's groundwater leaves it vulnerable to over-drafting, salinization and chemical contamination. Given the high cost of going to court to allocate groundwater rights as well as strong grassroots opposition, judicial adjudication is not a viable option for the near future. More importantly, the allocation of groundwater quantities in terms of a "safe yield" for the basin क्. will hamper its value as a flexible drought-year buffer. A safe yield is a pumping rate that does not deplete the groundwater basin over time.

An alternative to groundwater adjudication or central management is the simple system of pump measuring water withdrawals and charging for their replacement as practiced by the Orange County Water Agency for the past 30 years (Blomquist 1992). During this time, the state has experienced two severe droughts (1975 to 1977 and 1987 to 1992), in which the Orange County basins were drawn down and subsequently replenished. In addition to managing the long-term overdraft and preserving the buffer function of the groundwater, the pump tax and "basin equity assessments" that Blomquist describes provided sufficient incentives to maintain the district's hydrologic barriers to seawater intrusions that threaten the aquifer.

The flexible pricing system has the ability to supply alternative sources of reclaimed or surface water to users in areas that would induce salt contamination if left to obtain their supplies from pumping. The Orange County system of charging the replacement cost of all groundwater in excess of an allocated "basin production percentage" has controlled both groundwater quantity and quality without resorting to the costly and fractious process of quantity adjudication by the courts. In addition, users are free to decide on 
their optimal pumping strategy depending on the year and the cost of replacing excess pumping.

Threats to water quality. In the San Joaquin Valley, the quality threat to the water system comes from saline drain flows and deep percolation. The salt load originates partly from imported water and partly from leaching through saline soils. The long-term salt balance in the San Joaquin Valley is clearly not sustainable. Orlob (1991) showed that the San Joaquin Valley has been in a state of salt imbalance since 1951, and in 1989 had an annual accretion to the salt load of a million tons. The study demonstrated that the annual accretion is a function of hydrologic conditions and ranges from 210 tons in dry and below-normal years to 1 million tons in wet years.

In the long run, a sustainable system must be able to efficiently remove or store concentrated salts. Currently, salt export solutions for the San Joaquin Valley are not environmentally acceptable, so an alternative would be to minimize and concentrate the salt loads. Measurements in recent dry and drought years have shown that reductions in irrigated acres and changes in the efficiency of water use can substantially reduce the drainage volume and salt load to levels that can be concentrated and isolated by evaporation and bioaccumulation methods, such as salt-tolerant trees and shrubs.

Weinberg et al. (1993) show how the introduction of water markets can provide incentives to reduce irrigation drainage water, with a $30 \%$ reduction in drainage achievable if water is priced at a realistic $\$ 96 /$ acre-foot. The reduction in drainage comes from an increase in irrigation efficiency and a small increment in fallowed acres. Although a pure command-and-control system that dictates irrigation technologies has theoretically lower costs, the political feasibility of the market system is much greater. The ability to combine voluntary dry-year supply market options with drainage reduc- tion shows that the same social policy method can reduce both the quantity and quality threats to a long-term stable irrigated system.

\section{Future in focus: Toward a stable hydraulic society}

Although hydraulic societies are inherently ecologically unstable due to their modification and specialization of the ecosystem, changing the system of social feedback can compensate for this rigidity. The feedback that is required is one that is responsive to changing environmental and social conditions and has a wide range of information on possible technological and social adaptations. In recent years, an environmental water sector has emerged in California, consisting of governmental and nongovernmental organizations such as the U.S. Department of the Interior, the California Department of Fish and Game, anglers and Bay Area residents who advocate for increased water allocations to wildlife and habitat. This sector has acted both as a check on the expansion of irrigated areas and as a stimulant for the market reallocation of existing supplies by lobbying for legislation such as CALFED and the Central Valley Project Improvement Act. Environmental water uses may have the same effect on California as the Nile floods on ancient Egypt, if they can provide the incentives and constraints that history has shown are needed for a stable hydraulic society.

R.E. Howitt is Professor, Department of Agriculture and Resource Economics, UC Davis.
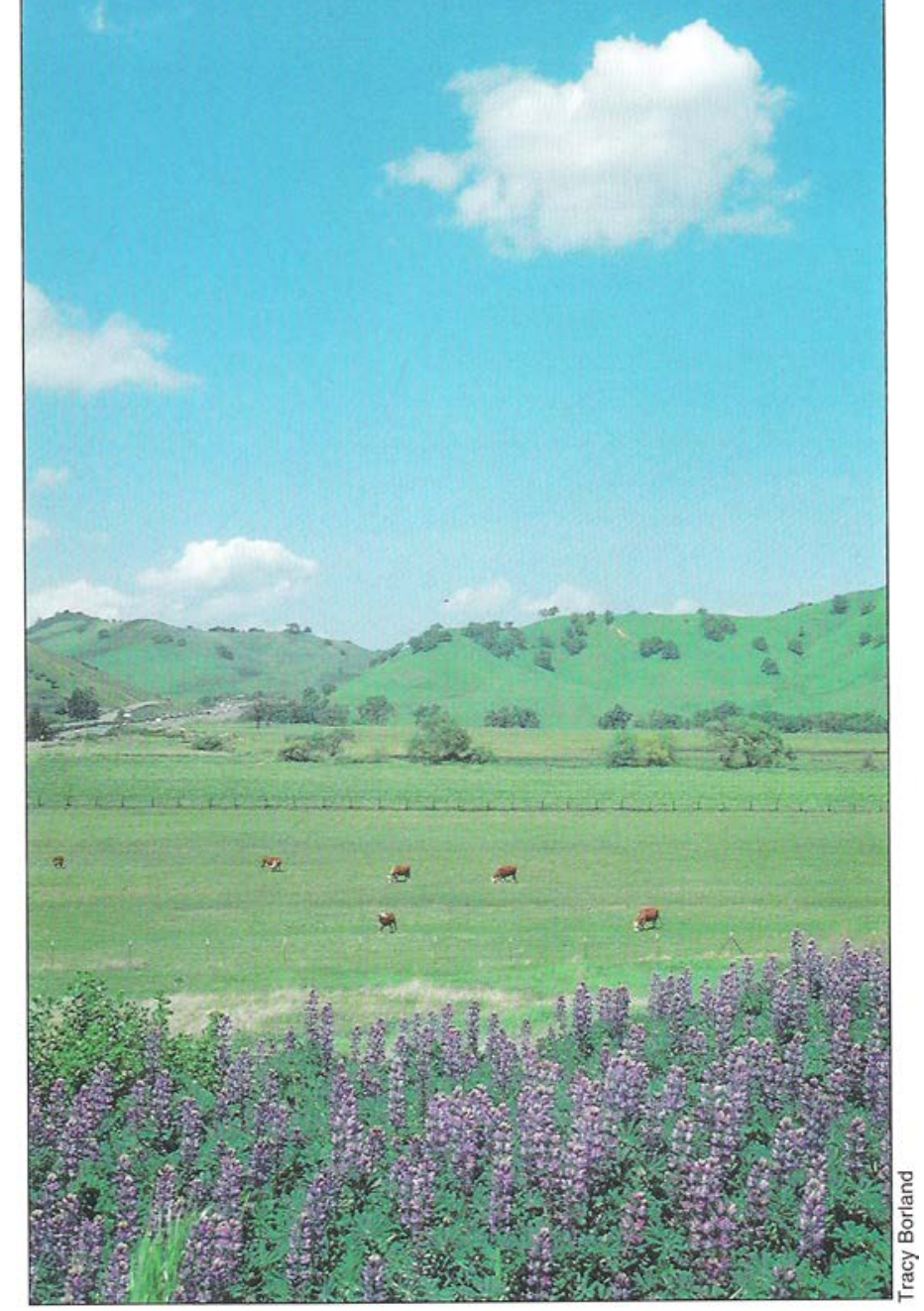

Wealthy, populous, industrial societies are often protective of their remaining agriculture, which provides amenities such as self-supporting open space and groundwater recharge.

\section{References}

Blomquist W. 1992. Dividing the Waters: Governing Groundwater in Southern California. San Francisco: CS Press. 415 p.

CALFED Bay-Delta Program. 1999. Draft Programmatic EIS/EIR Technical Appendix. Sacramento, CA. $100 \mathrm{p}$.

Kerr RA. 1998. Acid rain control: Success on the cheap. Science 282:1024.

Orlob GT. 1991. San Joaquin salt balance: Future prospects and possible solutions. In: Dinar A, Zilberman D (eds.). The Economics and Management of Water and Drainage in Agriculture. Boston: Kluwer. p 143-68.

Weinberg M, Kling CL, Wilen JE. 1993. Water markets and water quality. Am J Ag Econ 75:278-91.

Wittfogel KA. 1957. Oriental Despotism: A Comparative Study of Total Power. New Haven, CT: Yale University Press. 